\title{
p53 Immunoexpression in Oral Squamous Cell Carcinomas from Different Anatomical Sites: A Comparative Study
}

\author{
Inmunoexpresión de p53 en Carcinomas de Células Escamosas Orales \\ de Sitios Anatómicos Distintos: Un Estudio Comparativo \\ "Cláudia T. Sá; "* Linaena M. S. Fonseca;" Sérgio V. Cardoso; *"Maria Cássia F. Aguiar \& ** Maria Auxiliadora V. do Carmo
}

SÁ, C. T.; FOnSECA, L. M. S.; CARDOSO, S. V.; AGUIAR, M. C. F.\& CARMO, M. A. p53 immunoexpression in oral squamous cell carcinomas from different anatomical sites: A comparative study. Int. J. Morphol., 24(2):231-238, 2006.

SUMMARY: p53 alterations have been implicated in oral carcinogenesis process. Squamous cell carcinoma is the most common malignancy of the oral cavity, the tongue being the most frequent affected site. The aim of this study was to compare p53 immunoexpression in 43 samples of oral SCC from 5 different anatomical sites: tongue, floor of the mouth, alveolar ridge/gingiva, retromolar region and other regions of the oral cavity. Thirty-three lesions (76,8\%) showed positivity for p53 (mean index of 48,37\%). No statistically significant differences were found between 553 expression and the different oral sites analyzed. Similarly, no differences were found when comparing tongue lesions with the remaining sites. These results suggest that it might not exist any difference among oral cavity anatomical sites in relation to p53 immunoexpression. Moreover, mechanisms other than p53 alterations in squamous cell carcinomas of the tongue may be of relevance for the higher tumour aggressiveness found in this anatomical site.

KEY WORDS: p53 protein; Immunohistochemistry; Oral squamous cell carcinoma (OSCC).

\section{INTRODUCTION}

Squamous cell carcinoma is the most common intraoral malignancy (Scully \& Porter, 2000), and mainly affects male patients with ages varying between 40-80 years (Regezi et al., 1999; Scully \& Porter and Neville \& Day, 2002), although recent studies (Regezi et al.) have reported the occurrence of this malignancy in younger patients. Tobacco and betel use, alcohol consumption, viruses, and other occupational and environmental factors have been implicated in the etiology of the disease (Wünch-Filho, 2002).

With respect to the primary anatomical site, oral squamous cell carcinoma (OSCC) lesions mostly occur at the tongue, followed by floor of the mouth, alveolar ridge/ gingiva, buccal mucosa, labial mucosa and hard palate (Scully \& Porter and Neville \& Day). Lesions located at the tongue, specially at ventral surfaces and posterior lateral borders, account for around $40 \%$ of all cases in the oral cavity proper (Nagler et al., 2002 and Neville \& Day) and are still characterized by a poor prognosis due to the high potential for local invasiveness and great propensity to metastasis to cervical lymph nodes, thus affecting the probability of local control and survival (O-Charoenrat et al., 2003). In around $35 \%$ of the cases, regional disease is already present by the time of the diagnosis, reducing the 5-year survival rate to values lower than 20\% (Dias et al., 2001). Some studies conducted in animal models (Von Pressentin et al., 1999 and Schwartz et al., 2000) have tried to verify the effects of chemical carcinogens in various tissues, including oral mucosa, as it seems to have a significant role in the metabolic activation of carcinogens due to the amount of some enzymes responsible for this metabolic process. According to Von Pressentin et al. (1996), the tongue mucosa has a larger amount of these enzymes than other regions of the oral cavity, which raises a possible explanation for the higher aggressiveness and frequency of SCC in this site in particular. Also, the floor of the mouth and lateral and ventral tongue surfaces are covered by a thinner, nonkeratinized mucosa which provides less protection against carcinogens (Neville \& Day).

DDS, MS. Department of Dentistry, Public Ministry of Pará State, Brazil.

** DDS, MS, PhD. Department of Oral Pathology, School of Dentistry, Federal University of Minas Gerais, Brazil. 
Alterations in tumour suppressor genes, like TP53, are frequently found in various types of cancer and have been considered as molecular markers of cancer (Nagler, 2002), and $\mathrm{p} 53$ protein detection by immunohistochemistry has shown to be a reliable tool as indicative of alterations at gene level, since wild-type p53 has a short half-life and is theoretically not detectable by this method (Nylander et al., 2000 and Gonzalez-Moles et al., 2001). Moreover, some studies (Kropveld et al., 1999 and Balz et al., 2003) have shown that the analysis of the entire coding region of TP53 (exons 2-11) in head and neck SCC increases the frequency of mutations and yields a greater concordance level with immunohistochemistry results, although many caveats may lead to false-positive or false-negative results (Piffkó et al., 1995; Dowell \& Ogden, 1996; McNicol \& Richmond, 1998; Stoll et al., 1998; Saunders et al., 1999; Nylander et al. and Gonzalez-Moles et al.).

In the literature, p53 immunoexpression in OSCC ranges between 19-94\% of the cases (Warnakulasuriya \& Johnson, 1992; Kerdpon et al., 1997; Stoll et al.; Ünal et al., 1999 and Gonzalez-Moles et al.) and many factors may have influenced the variability of these results, like tumour material type and heterogeneity of tumoral sites (Saunders et al.). For this reason, we aimed to investigate, by means of immunohistochemistry, p53 immunostaining pattern in 43 samples of OSCC from different anatomical sites and compare p53 results in tongue squamous cell carcinomas with the remaining oral cavity sites.

This study was submitted and approved by the Ethics Committee (COEP) of Federal University of Minas Gerais, Brazil.

\section{MATERIAL AND METHOD}

Selection of Cases. Forty-three samples of primary untreated oral squamous cell carcinomas were randomly selected from the archives of the Laboratory of Oral Pathology, School of Dentistry, Federal University of Minas Gerais (Brazil), for comparing p53 antigen immunohistochemical staining in relation to the anatomical site of origin. Clinical data such as sex, age and location were obtained retrospectively from the anatomopathological records. All tumour specimens were $10 \%$ formalin-fixed and embedded in paraffin.

Immunohistochemical study. Immunohistochemistry reactions for detection of $\mathrm{p} 53$ antigen were performed with the monoclonal antibody DO-1 (Santa Cruz Biotechnology, Santa Cruz, USA). Tissue sections $(3 \mu \mathrm{m})$ were plated on pretreated slides (3-aminopropyltriethoxy-silano). It was followed by dewaxing and rehydration in descendant grades of ethanol. Then, slides were immersed in $1 \mathrm{mM}$ ethylenediamine tetra acetic acid (EDTA) buffer, $\mathrm{pH} 8.2$, and submitted to steam environment for 25 minutes, at $95^{\circ} \mathrm{C}$, for antigen retrieval. After cooling and washing in distilled water, sections were subsequently submitted to intrinsic enzymatic activity blocking $\left(\mathrm{H}_{2} \mathrm{O}_{2} 10 \%\right)$. After blocking procedures, sections were incubated in primary antibody (dilution 1:100) in a wet chamber, overnight, at $4^{\circ} \mathrm{C}$. Immune reactions were amplified by sequential incubation with biotinylated anti-mouse immunoglobulin and peroxidaselabeled streptavidin using commercial LSAB+ kit (Dako, Carpinteria, USA) according to manufacturer's instructions. Reactions were revealed by peroxidase activity in diaminobenzidine (DAB) chromogen substrate, counterstained with Mayer's haematoxylin and mounted in Permount (Fisher Scientific, Fair Lawn, USA). A positive control, consisting of a known p53-positive case of OSCC, and a negative control obtained by omitting the primary specific antibody were included in assays. Indexes for p53 expression were constructed based on a percentage of labeled cells among five hundred cells counted in at least three histological fields (400x), randomly chosen for each case in the most representative areas of tumours. Overexpression was considered for those cases with indexes higher than $10 \%$ (Sittel et al., 1999).

Statistical Analysis. For comparing p53 immunostaining indexes, as well as p53-positive or negative lesions, with tumour location, age and sex of patients, non-parametrical tests were applied: Kruskal-Wallis test, Spearman test of correlation, Mann Whitney test and Fisher Exact test. The analyses were performed using the statistical software package Biostat 3.0 (Ayres et al., 2003). Tests were considered statistically significant when their $\mathrm{p}$ values were lower than 0.05 .

\section{RESULTS}

Descriptive Statistics. Immunohistochemical analysis of p53 was performed on the OSCC lesions of 43 patients, being $35(81.4 \%)$ men and $8(18.6 \%)$ women. The mean age was $58.6 \pm 12.6$ years (39-82 years). OSCC samples were grouped accordingly to primary anatomical site as follows: tongue $(18 ; 41.86 \%)$, floor of the mouth $(8 ; 18.60 \%)$, alveolar ridge/ gingiva $(6 ; 13.95 \%)$, and retromolar region $(4 ; 9.30 \%)$. Due to the lower frequency of occurrence, lesions located at lip mucosa $(n=3)$, mandible $(n=2)$, maxillary tuber $(n=1)$ and buccal mucosa $(n=1)$ were clustered into one single group named other regions of the oral cavity, representing $16.27 \%$ of the samples. 
Table I. p53 immunostaining distribution in OSCC lesions, accordingly to primary anatomical site.

\begin{tabular}{lccc}
\hline Tumour location & $\mathrm{N}$ & $\mathrm{p} 53+$ & $\mathrm{p} 53-$ \\
Tongue & 18 & $14(77.8 \%)$ & $4(22.2 \%)$ \\
Floor of the mouth & 8 & $7(87.5 \%)$ & $1(12.5 \%)$ \\
Alveolar ridge/gingiva & 6 & $4(66.7 \%)$ & $2(33.3 \%)$ \\
Retromolar region & 4 & $3(75.0 \%)$ & $1(25.0 \%)$ \\
Other regions of the oral cavity & 7 & $5(71.5 \%)$ & $2(28.5 \%)$ \\
TOTAL & 43 & $33(76.8 \%)$ & $10(23.2 \%)$ \\
\hline
\end{tabular}

$\mathrm{N}=$ number of cases; $\mathrm{p} 53+=\mathrm{p} 53$-positive cases; $\mathrm{p} 53-=\mathrm{p} 53$-negative cases.

Table II. Mean p53-indexes in OSCC lesions, accordingly to primary anatomical site.

\begin{tabular}{lccc}
\hline Tumour location & p53 (\%) & \pm SD (\%) & $p$ value \\
\hline Tongue & $48.0 \%$ & $30.4 \%$ & $p=0.96^{\mathrm{a}}(\mathrm{n} . \mathrm{s})$ \\
Floor of the mouth & $64.2 \%$ & $29.0 \%$ & $p=0.14^{\mathrm{b}}(\mathrm{n} . \mathrm{s})$ \\
Alveolar ridge/gingiva & $40.0 \%$ & $32.2 \%$ & $p=0.50^{\mathrm{b}}(\mathrm{n} . \mathrm{s})$ \\
Retromolar region & $49.2 \%$ & $33.3 \%$ & $p=1.00^{\mathrm{b}}(\mathrm{n} . \mathrm{s})$ \\
Other regions of the oral cavity & $37.8 \%$ & $31.3 \%$ & $p=0.39^{\mathrm{b}}(\mathrm{n} . \mathrm{s})$
\end{tabular}

$\mathrm{SD}=$ Standard deviation; $\mathrm{n} . \mathrm{s}=$ statistically not significant;

${ }^{\mathrm{a}} \mathrm{p}$ value of tongue cases compared with the remaining sites, grouped; ${ }^{\mathrm{b}} \mathrm{p}$ value of tongue cases compared with the remaining sites, singly.

Table III. Comparison between p53 immunostaining and clinical variables in OSCC lesions.

\begin{tabular}{|c|c|c|c|c|}
\hline Variable & & $\mathrm{p} 53+$ & p53 - & $p$ value \\
\hline Age & & 33 & 10 & 0.77 \\
\hline \multirow[t]{2}{*}{ Gender } & M & 27 & 8 & 0.98 \\
\hline & $\mathrm{F}$ & 6 & 2 & \\
\hline Tongue with & & 14 & 4 & 1.00 \\
\hline the remaining sites, grouped & & 19 & 6 & \\
\hline Tongue with & & 14 & 4 & 1.00 \\
\hline floor of the mouth & & 7 & 1 & \\
\hline Tongue with & & 14 & 4 & 0.61 \\
\hline alveolar ridge/gingiva & & 4 & 2 & \\
\hline Tongue with & & 14 & 4 & 0.97 \\
\hline retromolar region & & 3 & 1 & \\
\hline Tongue with & & 14 & 4 & 0.99 \\
\hline other regions of the oral cavity & & 5 & 2 & \\
\hline
\end{tabular}

$\mathrm{M}=$ male; $\mathrm{F}=$ female; $\mathrm{p} 53+=\mathrm{p} 53$-positive cases; $\mathrm{p} 53$ - = p53-negative cases. 
p53 immunostaining. p53 immunoreactivity was restricted to the nuclei, generally with high intensity (Fig. 1 , A and B). Mean p53-index was $48.37 \pm 30.56 \%$, ranging between $0-91.7 \%$. Thirty-three lesions $(76.8 \%)$ showed positivity for p53 (Table I).

Comparison of p53 immunostaining with primary anatomical site. No statistically significant difference in p53 immunoexpression mean indexes was observed with respect to the anatomical site $(\mathrm{p}=0.34)$. Also, p53 immunoexpression in tongue cases did not differ from the other sites, grouped or singly, as shows Table II. When tongue cases were excluded from the analysis, there were no significant differences among the remaining anatomical sites $(p=0.23)$. Also, it was not observed any statistically significant difference when these remaining sites were analyzed two by two: floor of the mouth with alveolar ridge $(\mathrm{p}=0.09)$, retromolar region $(\mathrm{p}=0.35)$ and other regions of the oral cavity $(\mathrm{p}=0.08)$; alveolar ridge with retromolar region $(\mathrm{p}=0.52)$, and other regions of the oral cavity $(\mathrm{p}=1.00)$; and retromolar region with other regions of the oral cavity $(\mathrm{p}=0.57)$.

Comparison of p53 immunostaining with clinical data. p53 immunoexpression mean-indexes were not significantly associated with the other clinical variables analyzed: sex $(p=0.61)$ and age $(p=0.97)$ of patients. Mean $\mathrm{p} 53$-indexes found in male and female gender were $47.5 \%$ and $51.8 \%$, respectively.

p53-positive and p53-negative cases in relation to age, sex and primary anatomical site. Considering p53-positive and p53-negative cases, no statistically significant differences were found concerning age $(\mathrm{p}=$ $0.77)$ and sex $(p=0.98)$ of patients, as well as between tongue cases compared with the remaining sites, grouped $(p=1.00)$ or singly: floor of the mouth $(p=1.00)$, alveolar ridge $(\mathrm{p}=0.61)$, retromolar region $(\mathrm{p}=0.97)$, and other regions of the oral cavity $(\mathrm{p}=0.99)$; Table III.

\section{DISCUSSION}

In the present study, we did not find any correlation between p53 immunoexpression with respect to primary anatomical site in 43 samples of OSCC. These findings are similar to other papers (Warnakulasuriya \& Johnson, and Kerdpon et al.). Mean p53-index was $48.37 \%$ with 33 cases $(76.8 \%$ ) showing positivity for $\mathrm{p} 53$ protein, being within the range of other published findings (Warnakulasuriya \& Johnson; Kerdpon et al.; Stoll et al.; Ünal et al. and Gonzalez-Moles et al.). Some factors have been considered to influence such discrepancy, such as the methodology employed, type of tumour material and heterogeneity of tumoral sites examined (Saunders et al.). We did not aim to analyze our samples at gene level, thus the detection of mutant p53 cannot be confirmed although immunohistochemistry technique has assured its importance by the concordance level found in some recent studies (Kropveld et al. and; Balz et al.) between p53 protein expression mean-indexes and the presence of TP53 gene alterations. It is noteworthy that these studies have analyzed not only hotspots regions (exons 5-9), but the entire coding region of TP53 gene. Nevertheless, the study of Cruz et al. has established a cut-off value of $25 \%$ of p53 immunostained tumoral cells as indicative of TP53 mutations. False-positive results may have occurred leading to our $76.8 \%$ p53-positive cases, such as p53 upregulation in an attempt to promote DNA repair or apoptosis. Similarly, p53 stabilization and accumulation could be the result of p53 binding to cellular or viral proteins (Stoll et al.; Saunders et al.; Nylander et al. and Gonzalez-Moles et al.). Type and dilution of primary antibody (Piffkó et al.; Stoll et al.; Saunders et al. and Gonzalez-Moles et al.) as well as pre-treatment use (Dowell \& Ogden and McNicol \& Richmond) are also factors of influence in immunohistochemistry results. On the other hand, we have concluded that our p53-negative cases, apart from technique failures, may result from biallelic deletion of TP53 gene, very low levels of mutant or wild-type p53, a nonsense mutation or a truncated p53 protein in its $\mathrm{N}$-terminal portion, which would not be recognized by DO-1 antibody (Dowell \& Ogden; Stoll et al.; Saunders et al.; and Nylander et al.). Another possible explanation would be an accumulation of $\mathrm{Mdm} 2$ protein caused by gene amplification, promoting p53 degradation and non-detection by immunohistochemistry (Michael \& Oren, 2003).

Almost $50 \%$ of our samples were tongue tumours, which is in accordance with the literature (Neville \& Day). Although wide local excision is usually possible, tumours occurring in this region have high recurrence and mortality rates, reaching values of around 50\% (Ünal et al. and Nagler et al.). The rich lymphatic network of the tongue and floor of the mouth seems to favour an early dissemination of the disease to cervical lymph nodes, decreasing the 5-year survival rate to values lower than 20\% (Dias et al.). Moreover, experimental studies have shown that tongue tissue displays a higher amount of some enzymes responsible for the metabolic activation of chemical carcinogens than other oral tissues (Von Pressentin et al.). Nevertheless, the floor of the mouth and lateral and ventral tongue surfaces are characterized by a higher permeability due to their thinner, nonkeratinized 



Fig. 1. p53 immunolabeling in oral squamous cell carcinoma A: (100x); B: (400x). 
mucosa, providing less protection against carcinogens (Neville \& Day). These features may give a possible explanation for the high frequency and aggressiveness of tongue tumours. Perineural invasion, tumoral stage (T) and nodal metastasis have been considered as the most important parameters to predict tongue SCC recurrence (Ünal et al.). For all the aforementioned characteristics, we aimed to compare p53 protein immunostaining in tongue SCC cases with the remaining oral cavity sites. However, no statistically significant results were found and comparisons could not be made with other studies as they did not objectify to compare tongue tumours with other oral sites specifically (Warnakulasuriya \& Johnson; Kerdpon et al. and Nylander et al.). Even when tongue cases were excluded from the analysis, the remaining cases did not show correlation with p53. This lack of association between p53 immunostaining in tongue SCC and the remaining oral cavity sites, led us to suppose that other molecular and clinicopathological factors may have some relationship with the prevalence of the disease at the tongue. Probably, mechanisms other than p53 alterations may be of relevance for oral carcinogenesis (Nylander et $a l$.), thus, other investigations considering different varia- bles deserve to be continued until the elucidation of the specific mechanisms involving tongue carcinogenesis process. It is also interesting to point out the great similarities between the tongue and the floor of the mouth mucosas, the two most frequent locations for OSCC, such as the abundance of lymphatic vessels which may facilitate metastasis to cervical lymph nodes (Dias et al.). Equally, we should consider that the diagnosis of these lesions are established, most of the times, lately, and sometimes both sites are affected simultaneously, making it difficult to determine the primary site of occurrence. Hence, it is possible that the assembly of these two sites, compared with the remaining oral cavity regions, could have presented different results with respect to p53 immunostaining.

Considering our findings, we conclude that the various oral cavity anatomical sites do not differ from each other with respect to p53 immunostaining. Further investigations are required to elucidate the specific mechanisms involving tongue cancer as p53 did not appear to have influence in the higher frequency and more aggressiveness of the disease in this site particularly.

SÁ, C. T.; FONSECA, L. M. S.; CARDOSO, S. V.; AGUIAR, M. C. F.\& CARMO, M. A. Inmunoexpresión de p53 en carcinomas de células escamosas orales en sitios anatómicos distintos: Un estudio comparativo. Int. J. Morphol., 24(2):231-238, 2006.

RESUMEN: Las alteraciones de la p53 han sido implicadas en el proceso de carcinogénesis oral. El carcinoma de células escamosas es la malignidad más común de la cavidad oral, siendo la lengua el sitio afectado con mayor frecuencia. El objetivo de este estudio ha sido comparar la inmunoexpresión de la p53 en 43 muestras de carcinoma de células escamosas de la cavidad oral (CCEOs) de 5 sitios anatómicos distintos: lengua, piso bucal, encía/crista alveolar, región retromolar y otras regiones de la cavidad oral. Treinta y tres lesiones (el 76,8\%) han mostrado positividad para la p53 (índice promedio del 48,37\%). No han sido encontradas diferencias estadísticamente significantes entre la expresión de p53 y los diferentes sitios orales analizados. Similarmente, no han sido encontradas diferencias cuando comparadas las lesiones de lengua con los sitios remanentes. Estos resultados parecen sugerir la no existencia de diferencias entre los sitios anatómicos orales en cuanto a la inmunoexpresión de la p53. Además de eso, otros mecanismos, además de las alteraciones de la p53, en los CCEs de lengua, pueden tener relevancia en la mayor agresividad tumoral encontrada en este sitio anatómico en particular.

PALABRAS CLAVE: Proteína p53; Inmunohistoquímica; Carcinoma de células escamosas.

\section{REFERENCES}

Ayres, M. A.; Ayres Junior, M.; Ayres, D. L. \& Santos, A. S. Biostat. Versão 3.0. Belém, Sociedade Civil Mamirauá/ mct-cnpq, 2003. 292 p.

Balz, V.; Scheckenbach, K.; Götte, K.; Bockmühl, U.; Petersen, I. \& Bier, H. Is the p53 inactivation frequency in squamous cell carcinomas of the head and neck underestimated? Analysis of p53 exons 2-11 and human papilomavirus 16/18 e6 transcripts in 123 unselected tumor specimens. Cancer Res., 63:1188-91, 2003.
Cruz, I. B.; Snijders, P. J. F.; Van Houten, V.; Vosean, M.; Van Der Waal, L. \& Meijer, C. J. L. M. Specific p53 immunostaining patterns are associated with smoking habits in patients with oral squamous cell carcinomas. J. Clin. Pathol., 55:834-40, 2002.

Dias, F.L.; Kligerman, J.; Sá, G.M.; Arcuri, R. A.; Freitas, E. K.; Farias, T.; Matos, F. \& Lima, R. A. Elective neck dissection versus observation in stage I squamous cell carcinomas of the tongue and floor of the mouth. 
Otolaryngol. Head Neck Surg., 125:23-9, 2001.

Dowell, S. P. \& Ogden, G.R. The use of antigen retrieval for immunohistochemical detection of p53 overexpression in malignant and benign oral mucosa: A cautionary note. J. Oral Pathol. Med., 25:60-4, 1996.

Gonzalez-Moles, M. A.; Galindo, P.; Gutierrez-Fernandez, J.; Sanchez-Fernandez, E.; Rodriguez-Archilla, A.; Ruiz-Avila, I. \& Bravo, M. p53 protein expression in oral squamous cell carcinoma - survival analysis. Anticancer Res., 21:2889-94, 2001.

Kerdpon, D.; Rich, A. M. \& Reade, P. C. Expression of p53 in oral mucosal hyperplasia, dysplasia and squamous cell carcinoma. Oral Diseases, 3:86-92, 1997.

Kropveld, A.; Rozemuller, E. H.; Leppers, F. G. J.; Scheidel, K. C.; Weger, R. A.; Koole, R.; Hordjik, G. J.; Slootweg, P. J. \& Tilanus, M. G. J. Sequencing analysis of rna and dna of exons 1 through 11 shows p53 gene alterations to be present in almost $100 \%$ of head and neck squamous cell cancers. Lab. Invest., 79:347-53, 1999.

McNicol, A. M. \& Richmond, J. A. Optimizing immunohistochemistry: Antigen retrieval and signal amplification. Histopathology, 32:97-103, 1998.

Michael, D.; Oren, M. The p53-mdm2 module and the ubiquitin system. Semin. Cancer Biol., 13:49-58, 2003.

Nagler, R. M. Molecular aspects of oral cancer. Anticancer Res., 22:2977-80, 2002.

Nagler, R. M.; Kerner, H.; Laufer, D.; Ben-Eliezer, S.; Minkov, I. \& Ben-Itzhak, O. Squamous cell carcinoma of the tongue: the prevalence and prognostic roles of p53, bcl-2, c-erbb-2 and apoptotic rate as related to clinical and pathological characteristics in a retrospective study. Cancer Lett., 186:137-50, 2002.

Neville, B. W. \& Day, T. A. Oral cancer and precancerous lesions. CA Cancer J. Clin., 52:195-215, 2002.

Nylander, K.; Dabelsteen, E. \& Hall, P. A. The p53 molecule and its prognostic role in squamous cell carcinomas of the head and neck. J. Oral Pathol. Med., 29:413-25, 2000.
O-Charoenrat, P.; Pillai, G.; Patel, S.; Fisher, C.; Archer, D.; Eccles, S. \& Rhys-Evans, P. Tumour thickness predicts cervical nodal metastases and survival in early oral tongue cancer. Oral Oncol., 39:386-90, 2003.

Piffkó, J.; Bánkfalvi, A.; Öfner, D.; Berens, A.; Tkotz, T.; Joos, U.; Böcker, W. \& Schmid, K. W. Expression of p53 protein in oral squamous cell carcinomas and adjacent non-tumorous mucosa of the floor of the mouth: An archival immunohistochemical study using wet autoclave pretreatment for antigen retrieval. $J$. Oral Pathol. Med., 24:337-42, 1995.

Regezi, J. A.; Dekker, N. P.; McMillan, A.; Ramirez-Amador, V.; Meneses-Garcia, A.; Ruiz-Godoy Rivera, L. M.; Chrysomali, E. \& Ng, I. O. L. P53, p21, Rb, and $\mathrm{Mdm} 2$ proteins in tongue carcinoma from patients $<35$ versus >75 years. Oral Oncol., 35:379-83, 1999.

Saunders, M. E.; MaCkenzie, R.; Shipman, R.; Fransen, E.; Gilbert, R. \& Jordan, R. C. K. Patterns of p53 gene mutations in head and neck cancer: full-length gene sequencing and results of primary radiotherapy. Clin. Cancer Res., 5:2455-63, 1999.

Schwartz, J. L.; G, X.; Kittles, R. A.; Baptiste, A. \& Shklar, G. Experimental oral carcinoma of the tongue and buccal mucosa: possible biologic markers linked to cancers at two anatomic sites. Oral Oncol., 36:22535,2000 .

Scully, C.; Porter, S. Oral cancer. BMJ, 321:97-100, 2000.

Sittel, C.; Ruiz, S.; Volling, P.; Kvasnicka, H. M.; Jungehülsing, M. \& Eckel, H. E. Prognostic significance of ki-67 (mib1), pcna and p53 in cancer of the oropharynx and oral cavity. Oral Oncol., 35:583-9, 1999.

Stoll, C.; Baretton, G. \& Löhrs, U. The influence of p53 and associated factors on the outcome of pacients with oral squamous cell carcinoma. Virchows Arch., 433:427-33, 1998.

Ünal, O. F.; Ayhan, A. \& Hosal, A. S. Prognostic value of p53 expression and histopathological parameters in squamous cell carcinoma of oral tongue. J. Laryngol. Otol., 113:446-50, 1999.

Von Pressentin, M.; Kosinska, W. \& Guttenplan, J. B. Mutagenesis induced by oral carcinogens in lacz mouse (muta ${ }^{\mathrm{tm}}$ mouse) tongue and other oral tissues. Carcinogenesis, 20:2167-70, 1999. 
Warnakulasuriya, K. A. \& Johnson, N. W. Expression of p53 mutant nuclear phosphoprotein in oral carcinoma and potentially malignant oral lesions. J. Oral Pathol. Med., 21:404-8, 1992.

Wünch-Filho, V. The epidemiology of oral and pharynx cancer in Brazil. Oral Oncol., 38:737-46, 2002.

Correspondence to:

Mrs. Claudia Teixeira Sá

Ministério Público do Estado do Pará

Departamento Médico-Odontológico

Av. Dezesseis de $\mathcal{N o v e m b r o , ~} 130$

CEP: 66023-220

Belem (PA)

BRAZIL

Telepfione: + 55 - 91 - 32415666 Fax: +55 - 91 - 32419214

e-mail:claudiasa@mp.pa.gov.br

Recibido : 20-12-2005

Aceptado:27-02-2006 